\title{
ONE METHOD TO IMPROVE THE OFFICIAL POVERTY LINE IN INDONESIA
}

\author{
CARUNIA MULYA FIRDAUSY*
}

\begin{abstract}
Poverty is one of the long standing problems in Indonesia. Using the national absolute poverty line, it was estimated that the proportion of the poor has declined from $40.1 \%$ in 1976 to $10.5 \%$ in 20I4. However, many people claim that the above percentage of the poor is only true in terms of statistics. The poor argue that the amount of rupiah expenditure set as the official poverty line is inadequate to fulfil their basic needs. This paper, based on a field survey of 360 respondents of the poor and the non-poor in three villages in three different provinces located in the Eastern, Western and Central parts of Indonesia, aims at examining a method to improve the national poverty line and to determine the minimum rupiah expenditure of the poverty line using a subjective approach. The method used to examine this research question is by - using questionnaires, Focus Group Discussion (FGD) and in depth interviews. Sample respondents were asked their perceptions on variables, dimensions and indicators that should be accommodated in formulating the subjective poverty line. They were also questioned about the minimum rupiah expenditure threshold to define the subjective poverty line. The study found that the official poverty line that has been determined by the government was far below the subjective poverty line that was defined by the respondents. Also, the variables, dimension and indicators that should be accommodated in the national poverty line should not only be food items, but also access to employment, housing, health and education for children. The minimum rupiah expenditure of the poverty line was argued to be more than $\mathrm{Rp} 500$ ooo equal to US $\$ 40$ per capita per month. This minimum rupiah expenditure of the subjective poverty line is almost double that of the official poverty line set at the average of Rp 300 ooo or US\$24 per capita per month. Therefore, the government not only needs to revise the present poverty line, but also needs to revise policies and programs to eliminate poverty by taking into account the dimension and variables of poverty viewed by the poor and the non-poor. If not, the incidence of poverty will remain with us.
\end{abstract}

Keywords: absolute poverty line, subjective approach, expenditure of poverty line, basic needs, variables and dimension of poverty.

\begin{abstract}
Abstrak
Kemiskinan merupakan satu dari berbagai permasalahan lama di Indonesia. Dengan menggunakan garis kemiskinan absolut, proporsi penduduk miskin telah menurun dari 40,I\% tahun 1976 menjadi I0,5\% di tahun 20I4. Namun demikian, banyak yang menegaskan bahwa persentase kemiskinan tersebut bener secara statistik. Sementara orang miskin berpendapat bahwa besaran pengeluaran yang menjadi ukuran garis kemiskinan resmi tidaklah cukup untuk memenuhi kebutuhan dasar mereka. Artikel ini berdasarkan pada survei lapangan pada 360 responden masyarakat miskin dan tidak miskin di tiga desa dari tiga provinsi berbeda yang berlokasi di wilayah Indonesia bagian timur, barat, dan tengah dengan tujuan untuk menguji metode dalam memperbaiki garis kemiskinan nasional dan untuk menentukan besaran pengeluaran minimum dari garis kemiskinan dengan menggunakan pendekatan subyektif. Metode yang digunakan untuk menguji pertanyaan penelitian ini adalah dengan menggunakan kuesioner, diskusi kelompok terpumpun ( $F G D)$, dan wawancara mendalam. Responden yang menjadi sampel ditanyakan pendapat mereka terkait variabel, dimensi, dan indikator yang disesuaikan dengan
\end{abstract}

* Professor of Economics, Economics Research Centre, The Indonesian Institute of Sciences (LIPI), Jakarta, Indonesia. Email: cmfirdausy@gmail.com

Copyright (C) 2016 The Author. (C) 2016 Deputy of Social Sciences and Humanities. All rights reserved. Printed in Indonesia. Journal of Indonesian Social Sciences and Humanities (JISSH); Vol. 6, Issue I, (20I6), pp. 39-52.

ISSN: $1979-843$ I 
rumusan garis kemiskinan subyektif. Responden juga ditanyakan mengenai batas besaran pengeluaran minimum untuk mendefinisikan garis kemiskinan subyektif. Hasil temuan menunjukkan bahwa garis kemiskinan resmi yang telah ditetapkan oleh pemerintah masih berada jauh di bawah garis kemiskinan subyektif yang didefinisikan oleh responden. Selain itu, variabel, dimensi, dan indikator yang seharusnya disesuaikan dengan garis kemiskinan nasional tidak hanya pada makanan, tetapi juga akses terhadap pekerjaan, perumahan, kesehatan, dan pendidikan. Besaran pengeluaran minimum garis kemiskinan dinilai lebih dari Rp. 500.000 atau secara dengan US\$ 40 per kapita per bulan. Besaran pengeluaran minimum untuk ukuran garis kemiskinan subyektif ini menjadi hampir dua kali lipat dari yang telah ditetapkan, yaitu sekitar Rp. 300.00o atau US\$24 per kapita per bulan. Dengan demikian, pemerintah tidak hanya harus merevisi garis kemiskinan saat ini, tetapi juga harus meninjau kembali kebijakan dan program yag berupaya untuk mengurangi kemiskinan dengan memasukkan dimensi dan variabel kemiskinan menurut kelompok masyarakat miskin dan tidak miskin. Jika tidak, masalah kemiskinan masih akan terus ada.

Kata Kunci: garis kemiskinan absolute, pendekatan subyektif, pengeluaran garis kemiskinan, kebutuhan dasar, variabel dan dimensi kemiskinan

\section{INTRODUCTION}

Poverty is still one of the long standing problems in Indonesia. Although this country has experienced rapid economic growth at an average of $8.0 \%$ per year between 1976 and 1996 , the proportion of the poor has only decreased from $40.1 \%$ to II.3\% in those years. However, since $1997 / \mathrm{I} 998$ the proportion of the poor increased again to more than double to $24.2 \%$. This was because this country was hit hard by the economic crisis that occurred in Asia in I997/I998.

However, this significant increase in the proportion of the poor in 1998 was able to be reduced to 1996 levels of II.4\% by 2013. The Central Board of Satistics, using the national poverty line, estimated that the number of the poor in 2013 was 28.07 million people and it decreased slightly again to I0.5\% in 20I4. This number of the poor was similar to 20I2. In 2012 the number of the poor was estimated to be at 29.I million people (CBS, 2013). This indicated that between 2012 and 2013 rapid economic growth at annual average of $6 \%$ was only able to reduce the number of the poor by I.03 milion people. This inability of rapid growth to reduce the poor at a significant rate has occurred since 2009 , as shown in Figure I. Thus, this once again confirms that rapid economic growth is not sufficient to significantly reduce the incidence of poverty.

Beside criticisms of the use of growth policy to eliminate the incidence of poverty, there have also been criticisms regarding the concept and definition of the poverty line made by the government. It is argued that the present concept and definition of the absolute official poverty line that is based on the standard calorie intake should be reconsidered as it does not take into account protein intake. Also, because many food commodities with a high calorie intake can be purchased at low price. Hence, the absolute poverty line used to measure the incidence of poverty is unable to capture the real facts of the poor.

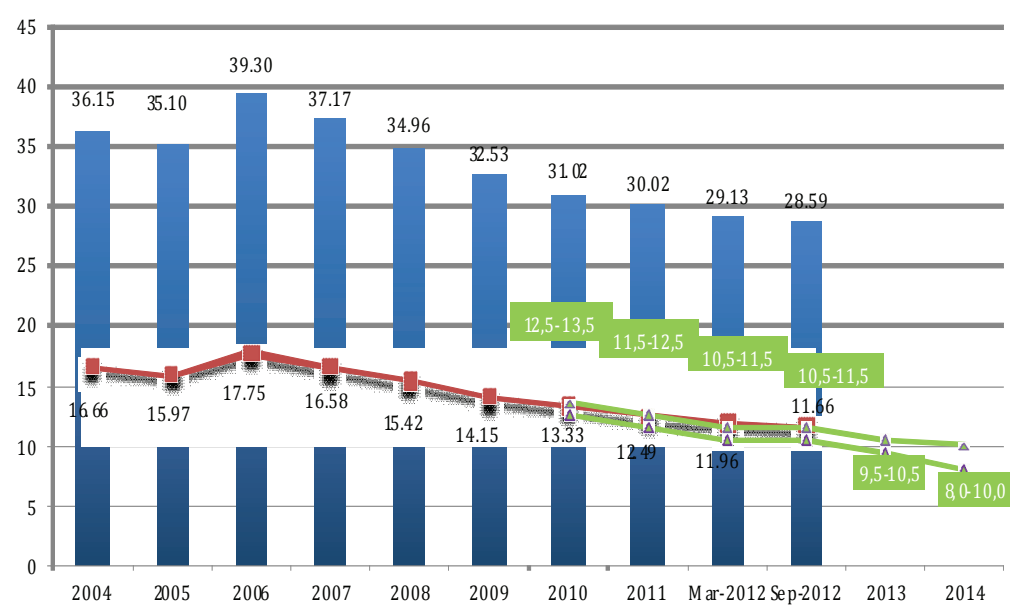

Source: Central Board of Statistics, 2004-2014

Figure I. The Proportion of the Poor 2004-20I4 
Other criticisms of the present national poverty line relate to the abritraryness in selecting the 52 items of food commodity baskets. This arbitraryness certainly affects the poverty line made by the government. Note also that the distinction of the poverty line made between rural and urban areas means that the non-poor in rural areas will be counted as the poor, if they migrate to urban areas (see Asra, 2013 for details). This condition will further mislead estimations of the number of the poor.

Due to the above criticisms, there have been many suggestions to seek other methods in defining the poor in Indonesia. Of these methods, the self-rated or subjective poverty line, has been widely suggested in the literature (see for instance, Mangahas, 2008; Van Praag and Carbonnel, 2006; Herrera et.al, 2006; and Firdausy, 20II). Others suggested the use of the World Bank Poverty line, and the relative poverty line (Wagle, 2002). Also, Alkire (20I0) and UNDP (2010) have suggested the importantance of a multidimensional poverty line as the method of estimating the incidence of poverty in Indonesia.

In response the suggestions above, the government through the Body of National Development Plan (Bappenas) has organized a series of national discussions to seek an alternative measure of the poverty line that is able to minimise the above drawbacks of the present official poverty line on one hand and can be used for decision making policy for increasing the welfare of the poor on the other. For this reason, this paper based on a field survey of 360 respondents of the poor and the non-poor in three villages in three different provinces located in the Eastern, Western and Central parts of Indonesia, aims at examining a method to improve the official poverty line and determine the minimum rupiah expenditure of the poverty line using the self rate or subjective approach.

Before the results of this study are discussed, this paper reviews the concept and definition of poverty line in the literature and examines the poverty lines that were used to estimate the poor in Indonesia as the background of the analysis in Section 2. The third section then explains the research methods used in the study. The fourth section discusses findings of the study with particular focus on the subjective poverty line based on socio-economic characteristics of the respondents. Finally, concluding remarks are drawn in Section 5.

\section{A BRIEF LITERATURE REVIEW}

\section{Concept and Definition of Poverty}

Literature on the concept and definition of poverty can be grouped into two categories. The first emphasises measurement-related poverty. The second deals with cause or factor-related poverty. The latter will not be discusssed here as the focus of this study is to examine the alternative concept and definition of the absolute poverty line.

The measurement of related poverty can be divided into two types, namely, static and dynamic. All of these concepts and definitions of poverty use their measurements based on the dimension of economic well-being. This economic well-being dimension is usually measured by an income, expenditure or welfare approach.

In terms of the static measures, however, poverty is divided into absolute poverty, relative poverty and subjective poverty. The first two poverty measures are usually used in one of the above three approaches of economic well being. But, for the subjective poverty, it is based on the perception or subjectivity of the population or household. While for the dynamic measure, this can be grouped into two, namely chronic and transient (see for details Asra, 2013).

The absolute poverty line is usually defined to reflect the inadequacy to fulfil basic needs. In this approach the poverty line is derived on the basis of the above variables objectively. Methods used to determine the absolute poverty line in this category can be based on Direct Calorie Intake (DCI), Food Energy Intake (FEI), or Cost of Basic Needs (CBN) methods (see Ravallion, I992)

The DCI method essentially measures the incidence of malnutrition rather than the incidence of poverty. This suggests that people 
who are lacking in calorie intake should not be considered as poor, but should be considered as malnurished. However, as poverty is usually correlated with the lack of food intake, people who have less food calorie intake are consequently considered as poor in the national statistics.

The DCI method calculates the daily consumption of food intake of the household and compares this with the consumption of food intake under the Recommended Dietary Daily Allowance (RDA) of 2.Ioo calorie per capita per day. Thus, households who have a daily consumption of food intake below this RDA are considered poor.

Unlike the DCI method, the Food Energy Intake (FEI) method is used by first calculating the minimum average of the food energy intake and then this average is converted into rupiah equivalent. This rupiah equivalent is then used as the expenditure poverty line (see details Ravallion, I992). Note that, this type of FEI poverty line has been argued to be misleading when it is used for comparisons of the incidence of poverty between regions or locations. The reason is simply because the FEI poverty line does not acommodate differences in taste, prices and individual activities (Ravallion, I992, p. 28).

Due to the reasons above, the Cost Basic Needs (CBN) approach was selected as the alternative method to measure the incidence of poverty in many countries, including Indonesia. Unlike the above two poverty lines, the CBN poverty line is determined on the basis of food basket and non-food baskets. The items that are included in the two baskets are the items which are considered basic needs items. All of the items in both food and non-food baskets are finally converted into rupiah as the official poverty line (See CBS, 2012).

Unlike the methods above, the self-rated or subjective poverty line is argued to be a simple method, easy to implement, quicker, more frequent and regular. This method is developed on the basis of an individual's perception towards the definition of poor (Goedhart, et.al, I977). This poverty line is used in many developed and developing countries. In the Philippines, for instance, this subjective poverty line has been used by Social Weather Station (SWS) since I983 to complement the poverty data collected by National Statistical Coordination Board, Phillipines. Mangahas (2008) argued that SWS is the world's most rapid and most up-to-date system for statistical monitoring of poverty and hunger in a country at the national level. Also, Gustafsson and Yue (2006) used this method to estimate the incidence of poverty in China in 2002. Using this method, they found that the proportion of the poor in rural areas of China has been similar to the estimate of the poor using the World Bank measure.

\section{Poverty Line Used in Indonesia}

There are two types of absolute poverty lines that have been used to estimate the number of the poor in Indonesia. The first type is the official poverty line that is established by the government through the Central Board of Statistics (CBS). The second types are the nonofficial poverty lines including the Sayogyo's poverty line, the World Bank poverty line amongst others (see Asra, 20Io).

For the official poverty line, however, there have been changes since I993. Before I993, the official absolute poverty line used to estimate the incidence of poverty was by the Food Energy Intake (FEI) method. In this method, any individual is considered poor if his/her daily consumption spending on food energy is under the minimum standard of the Recommended Dietary Allowance (RDA) at 2.I0o kilo calorie per capita per day (CBS, I994).

Since I993, however, this official FEI method has been changed to the Cost of Basic Needs (CBN) method. As explained previously, the $\mathrm{CBN}$ poverty line method bases the estimation of the costs spent by the individual to fulfil his/her basic needs. Basic needs here are defined not only by food items, but also by non-food items. The food items consist of 52 basic food items including rice, tubers, fish, meat, eggs and milk, vegetables, nuts and fruits. Whilst the non-food items include individual spendings on housing, clothing, health and education. By summing up both spendings on food and nonfood items, the government then determines the poverty line in rupiah terms. 
Apart from the use of the official poverty line above, there have been a number of poverty lines suggested and used as complementary measures of the incidence of poverty in Indonesia. The first of these is Sayogyo's poverty line. This poverty line was widely used to estimate the number of the poor in the I97os. The poor are defined under this poverty line as an individual who has income per year less than the equivalent of the price of 320 kilogram of rice. This poverty line is used to define the poor in rural areas. For the urban areas, however, the poverty line is defined as the individual who has income per year less than the equivalent of the price of 480 kilograms of rice (Asra, I992).

However, Sayogyo's poverty line has been criticized as having many drawbacks. This poverty line, for instance, was not sensitive to changes in the price of rice from one location to another. Also, changes in the price of rice are not always in line with changes in the price of non-rice goods. Thus, Sayogyo's poverty line, although it is quite simple and easy to use, is not sensitive to the changes in the price of rice from one place to another or to changes in the price as time changes.

Due to the above drawbacks, the World Bank followed by the Asian Development Bank suggested using \$I Purchasing Power Parity (PPP) per capita per day as the international poverty line (see David, Asra dan de Catsro, I999). This poverty line was then expanded to \$2 PPP per capita per day. However, using this poverty line it was found that the estimated proportion and number of the poor in Indonesia was different to the official poverty line. Consequently, the government continues to use the CBN method as the official poverty line to estimate the number of the poor in Indonesia today.

\section{RESEARCH METHOD}

As previously mentioned, this study aims to examine the alternative poverty line in Indonesia focusing on the self-rated or subjective approach suggested by Mangahas (2008). The examination of the subjective poverty line in the study is not only based on the respondents' perception of what variables and dimensions are considered important and should be be accommodated in the subjective poverty line, but it also seeks the minimum amount of rupiah required to cover the costs of these basic needs per capita per household per month.

To examine the above research questions, a field survey was undertaken in three villages located in three different districts and provinces, namely, the district of Bantul, Yogyakarta province (Central Indonesia), the district of Palembang, South Sumatera province (Western Indonesia) and the district of Gowa, South Sulawesi province (Eastern Indonesia). These three different survey locations were selected to sharpen the findings of the study.

Also, it was intended to minimise the effects of cultural and geographical differences of people in Indonesia that could affect the individual perception in determining their subjective views on the poverty line. Note that, the selection of the three districts considered differences in the proportion of the incidence of poverty. The district of Bantul (Jogyakarta province), for instance, has the highest proportion of the poor. While the district of Gowa (South Sulawesi province) and the district of Palembang (South Sumatra province) had a medium and a small number of the poor respectively.

After the three districts above were selected, two villages in each district were taken as sample survey locations. These villages were Panggungharjo and Triharjo villages which are located in the District Bantul (Jogyakarta province), Dua Puluh II and Karya Jaya in the District Palembang (South Sumatera province), and Tanrara and Bolaromang villages in the district of Gowa (South Sulawesi province).

Before the questionnaire was given out, a card was given to each respondent to state whether he/she is poor or not poor. Of the 360 respondents selected, it was found that about 66.7 percent of the respondents grouped themselves as poor, while the rest of 33.3 percent grouped themselves as non-poor. Note that, the method to select sample respondents in each village was by systematic random sampling from the sampling frame of each village provided by the local statistics office. 
In addition to questionnaires, an in depth interview with some of the poor and the non poor respondents was also done in the survey villages. This interview was intended to sharpen data and information collected from the questionnaires. Also, a Focus Group Discussion (FGD) with local resource persons including the formal and informal leaders was undertaken. This qualitative survey was intended to back up data and information collected from the quantitative survey using questionnaires. A field observation was also done in order to observe daily behaviour of the respondents surveyed as well as to minimise untruthful answers given by the respondents in completing questionnaires.

Data and information collected from in depth interviews included: a) the respondents' perception towards the subjective poverty line; $b$ ) details of food and non-food variables that must be included in the poverty line; and c) reasons why those variables are considered important. For the questionnaires, data collected included: a) characteristics of respondents consisting of age, sex, educational attainment, and employment status; b) data on income and expenditure per month; c) respondents' perception on what variables of food and non-food that must be accommodated in the poverty line; and d) respondent's perception on what is a standard minimum income/expenditure per capita per month as the subjective poverty line. Note that in this paper, the discussion will be limited only to findings related with the respondents' perception on the meaning of poor, the basic needs items of the poverty line, and the amount of rupiah expenditure to define poverty per capita per household per month based on social and economic characteristics.

\section{WHAT IS THE MEANING OF POOR?}

The meaning of poor viewed by the respondents surveyed was varied. However, as shown in Diagram I, only about $7.8 \%$ of respondents defined poverty as the lack of individual spendings to fulfill merely one basic needs item. The rest defined poverty as the lack of individual spending to fulfill more than one of the basic needs items. Of this group, the largest proportion of respondents defined poverty as the individual who has the lack of spending on two or three basic needs items. The proportion of respondents who defined poverty as an individual who has the lack of spending on more than three basic needs items was relatively small (Diagram I).

Note that, of the six basic needs items viewed as very important in defining a poor individual were food items. These food items were viewed as the main items that have to be accommodated in defining the poverty line. These food items can be combined with individual spending on social and cultural activities in the village, employment status, and a poor housing unit. Whereas for the items combining a the lack of spending on education and health were considered as the least important items in defining poverty. This is not surprising as these two non-food items have been provided free by the government in the villages surveyed.

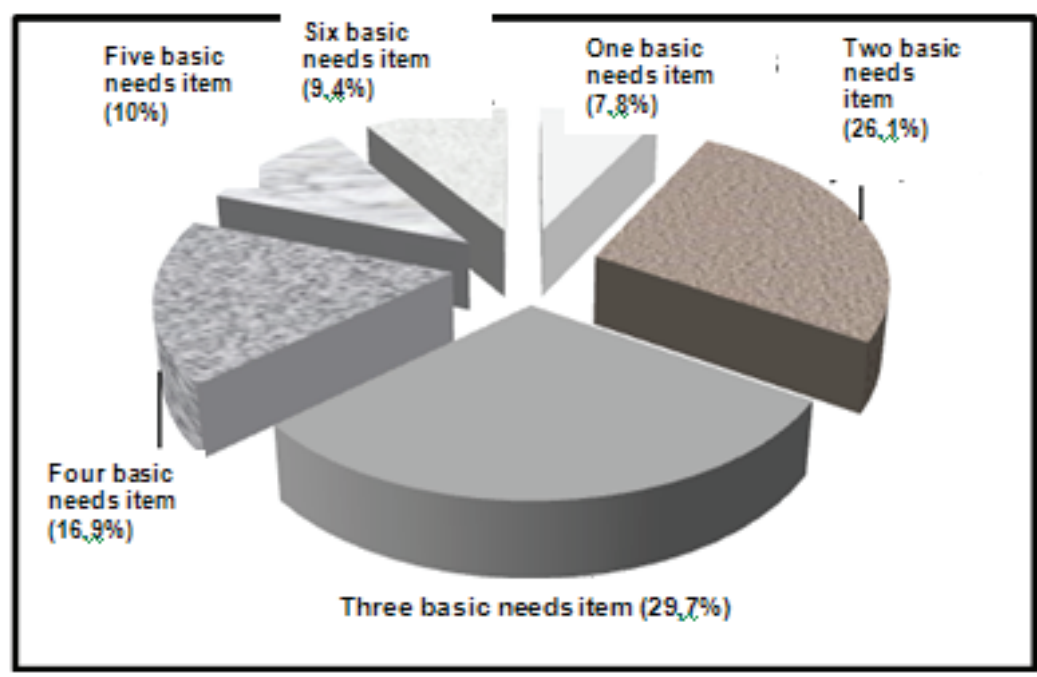

Source : data collected from villages survey, 2013.

Figure I. Respondents' Perceptions on the meaning of poorby the number of basic needs items (unit: percent) 
The above findings were also confirmed from the data,information collected during the in depth interview and Focus Group Discussion (FGD). During a FGD in Jogyakarta province, for instance, it was stated as follows:

".......the meaning of poor does not only related with food requirements for the daily needs, but it also associated with the non food items and the ability of the individual to share his/her income for any social and cultural contribution organised in the village. If any individual was not able to give any social and cultural contribution organized in the village, the individual was considered poor ..........."

A similar finding was also viewed by the participants of FGD's and in depth interviews in the village of Gowa in South Sulawesi province as well as in the city of Palembang, South Sumatra province. However, the emphasis stated by these FGD participants was not only on the lack of daily food consumption, but it was also related with clothing needs and a poor housing unit.

Table I. Respondents' Perception on the meaning of poor by educational level (unit: percent)

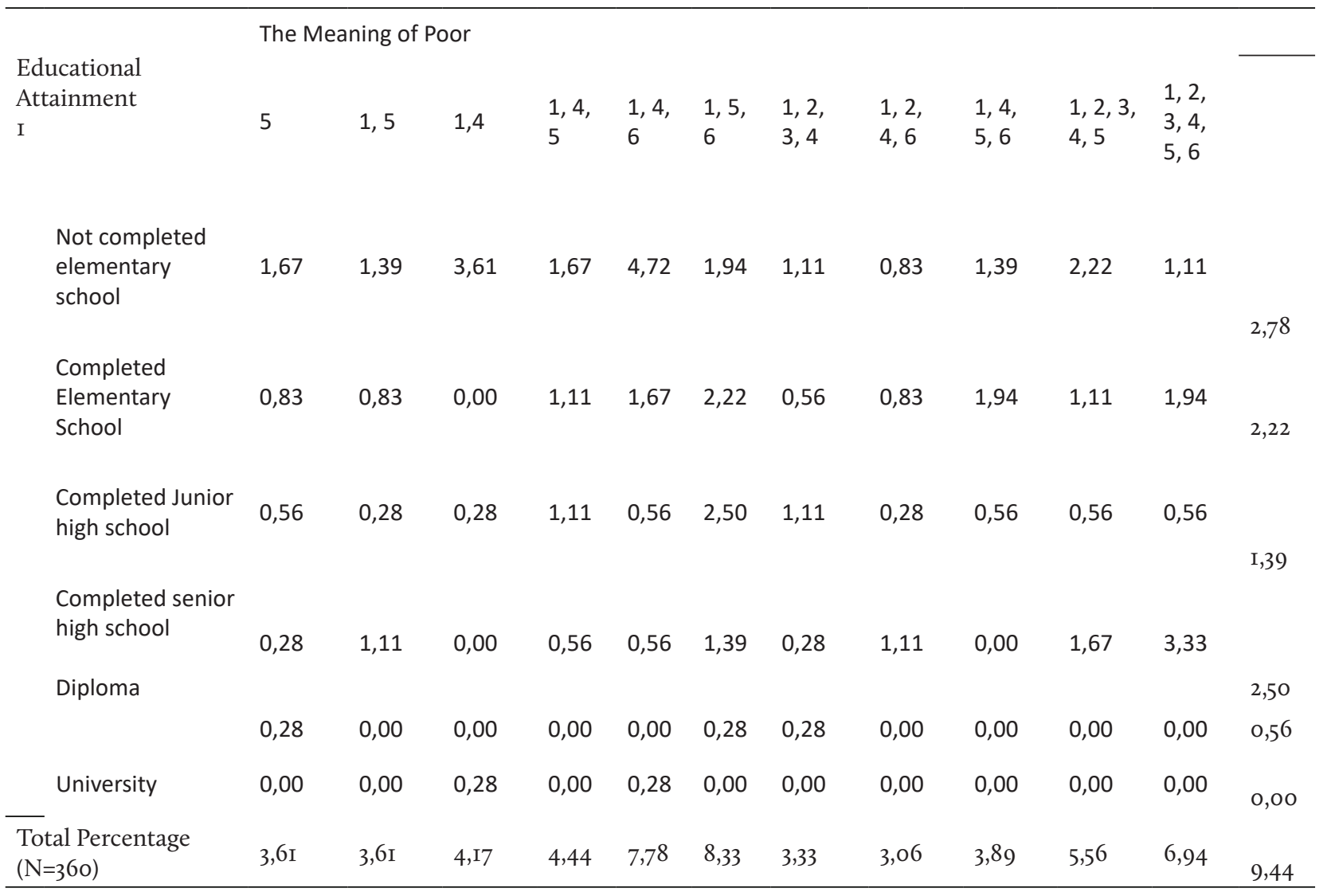

Note : I. Not enough food; 2 . Unable to hospital; 3 . Unable to send the children to school; 4. Poor housing unit; 5. Employment status; and 6. Others (social contribution).

- Total percentage for each item under 3 percent is not given so that the percentage is not Ioo percent.

Source : Data collected from villages survey, 2013.
The above views were also confirmed by respondents on the basis of education level. The respondents who have educational attainment lower than senior high school generally consumption whereas those respondents who have an educational background above senior high school defined poverty as an individual who does not only have the lack of spending on food consumption, but more importantly as the individual who has the lack of spending on nonfood consumption. Although the number of these respondents were not in large numbers, it certainly indicates that educational background has strong relationship with poverty definition. Thus, the decision to define the poverty line for this group should accommodate the importantance of spending on non-food items, apart from the spending on food items (Table I). defined poverty as the lack of spending on food 


\section{WHAT ARE THE DETAILS OF BASIC NEEDS ITEMS IN THE POVERTY LINE?}

As previously stated the poverty line should accommodate food and non-food items. However in terms of non-food items, the study found that the daily consumption of items such as soaps, tooth paste, towels and the like have been viewed as important. The proportion of respondents who stated these views was about 7.8 percent. This is followed by those respondents who stated the importantance of spending on traditional or cultural activity in the village (7 percent). For the non-food items such electricity, education and health, the proportion of the respondents in this category was only 6.I percent (Table 2). Therefore, differences on educational characteristics of the respondents does not show any differences in views ofdefining items that should be accommodated in the poverty line.
A similar finding was also found when the respondents were grouped in terms of the type of employment. As exhibited in Table 3, respondents for all types of employment defined that the meaning of poor for any individual is if she/he has no ability to fulfil his/her daily food and non-food items consumption. However, of the basic needs items that were considered a must to define poverty was the combination of food items and others and the combination of six basic needs items. These six basic needs items are inadequate daily food consumption, unable to go to health clinics when ill, unable to send children to school, poor housing unit, no job and others. This was followed by the combination of three basic needs items, namely, inadequate food consumption, poor housing unit and others. This again indicates that the meaning of poor does not solely relate to food consumption.

Table.2 Respondents' perception on the meaning of poor on the basis of basic need items by educational attainment (unit: percent)

\begin{tabular}{|c|c|c|c|c|c|}
\hline \multirow{2}{*}{\multicolumn{2}{|c|}{$\begin{array}{l}\text { Educational Level } \\
1,2\end{array}$}} & \multicolumn{3}{|c|}{ Basic Needs Items } & \\
\hline & & 1,9 & $1,2,3,4,5,6,7,8,9$ & $1,2,3,4,5,6,8$ & \\
\hline & Not completed elementary & 3,89 & 1,94 & 2,78 & 2,22 \\
\hline & Completed Elementary school & 1,94 & 2,78 & 0,28 & 0,83 \\
\hline & Completed Junior High School & 0,83 & 1,39 & 1,39 & 0,00 \\
\hline & Completed Senior High & 0,83 & 0,83 & 1,67 & 0,56 \\
\hline & Diploma & & & & \\
\hline & & 0,28 & 0,00 & 0,00 & 0,00 \\
\hline & University & 0,00 & 0,00 & 0,00 & 0,00 \\
\hline Total percentage & & 7,78 & 6,94 & 6,11 & 3,61 \\
\hline
\end{tabular}

Notes: I. Food items; 2 daily needs (soap, tooth paste and tooth brush); 3. Energy for cooking and transportation; 4. Education; 5. Health; 6. Electricity; 7. Telephone; 8. Social contribution; and 9. Others.

Total percentage for each item under 3 percent is not given so that the the percentage is not roo percent.

Source : Data collected from villages survey, 2013. 
Table 3. Respondents' Perception of the meaning of poor based on employment status (unit: percent)

\begin{tabular}{|c|c|c|c|c|c|c|c|}
\hline \multirow{2}{*}{$\begin{array}{l}\text { Type of Employ- } \\
\text { ment }\end{array}$} & \multicolumn{6}{|c|}{ Basic need items category } & \multirow[b]{2}{*}{$1,2,3,4,5,6$} \\
\hline & 1 & 1,4 & 1,6 & $1,4,5$ & $1,4,6$ & $1,4,5,6$ & \\
\hline $\begin{array}{l}\text { Government } \\
\text { official }\end{array}$ & 0,28 & 0,28 & 0 & 0,56 & 0,56 & 0 & 0 \\
\hline $\begin{array}{l}\text { Company's work- } \\
\text { ers }\end{array}$ & 0 & 0,28 & 0,28 & 0,56 & 0,28 & 0,28 & 0,28 \\
\hline Farmer & 0,56 & 1,94 & 3,33 & 2,22 & 3,33 & 1,39 & 1,67 \\
\hline Blue worker & 0,56 & 1,11 & 3,06 & 1,39 & 3,33 & 2,22 & 3,06 \\
\hline Informal sellers & 0,28 & 0,83 & 1,39 & 0,83 & 0,56 & 0,56 & 2,5 \\
\hline Husbandry & 0 & 0 & 0,28 & 0 & 0 & 0 & 0,56 \\
\hline House wife & 0,56 & 0 & 1,11 & 0,28 & 0 & 0,28 & 0 \\
\hline Entrepreneur & 0 & 0 & 0 & 0,56 & 0,28 & 0,56 & 0,56 \\
\hline Unemployed & 0,56 & 0 & 0,56 & 1,11 & 0 & 0 & 0 \\
\hline Others & 0,83 & 0 & 0,56 & 0 & 0 & 0,28 & 0,83 \\
\hline Total percentage & 3,61 & 4,44 & 10,56 & 7,5 & 8,33 & 5,56 & 9,44 \\
\hline
\end{tabular}

Note : I. Not enough food; 2 . Unable to go to hospital when sick; 3. Unable to send the children to school; 4. Poor housing unit; 5. Unemployed; and 6. Others (social contribution).

- Total percentage for each item under 3 percent is not given so that the the percentage is not roo percent.

Source : Data collected from villages survey, 2013.

However, of nine basic needs ítems of the poverty line, the study found that the combination of inadequate food consumption and other daily needs has the largest percentage. This was then followed by the combination of food items and others, and the combination of nine basic needs ítems (Table 4). This suggests that the type of employment has no significant relationship with judgement toward the poverty line. The meaning of poor based on the type of employment is the same as the meaning of poor based on educational level as discussed previously.

Finally, in terms of the number of household members and the amount household expenditure, the study also found that most of the respondents defined the meaning of poor as the combination of food as well as non-food items. In other words, the meaning of poor does not only relate to one particular basic needs item. This once again confirms that the components that need to be accommodated in defining the poor individual should not be based only on the food items, but it should be combined with other basic needs. There are at least 5 dimensions or variables that need to be accommodated in constructing the national poverty line. Apart from food adequacy, variables such as education, health, housing and employment are a must in defining the poor individual. 
Table 4. Respondents' Perceptions on the Type of Basic Needs to Define Poverty by Type of Employment (unit: Percent)

\begin{tabular}{llllll}
\hline & \multicolumn{5}{c}{ Basic needs item category } \\
Type of employment & 1,9 & 1,2 & $1,4,9$ & $1,2,3,4,5,6,7,8$ & $1,2,3,4,5,6,7,8,9$ \\
$\begin{array}{l}\text { Government } \\
\text { Officials }\end{array}$ & 0 & 0,56 & 0,28 & 0,28 & 0 \\
\hline Private workers & 0 & 0 & 0 & 0 & 0,28 \\
\hline Rice Farmers & 1,94 & 3,06 & 0 & 0,56 & 0,83 \\
\hline Blue collar workers & 3,06 & 1,94 & 1,67 & 0,83 & 3,33 \\
\hline Hawkers & 0,56 & 0 & 0,56 & 0,28 & 0,83 \\
\hline Husbandry farmers & 0 & 0 & 0 & 0 & 0,28 \\
\hline & & & & 0 & 0 \\
House wife & 0,28 & 0,83 & 0 & 0 & 0 \\
\hline Small traders & 0,56 & 0 & 0,56 & 0,28 & 0 \\
\hline Unemployed & 0,28 & 0,83 & 0 & 0,56 & 0,56 \\
\hline Others & 0 & 0,56 & 0,83 & 0,83 & 6,11 \\
\hline Total percentage & 6,67 & 7,78 & 3,89 & 3,61 & \\
\hline
\end{tabular}

Notes: I. Food items; 2 daily needs (soap, tooth paste and tooth brush); 3. Energy for cooking and transportation; 4. Education; 5. Health; 6. Electricity; 7. Telephone; 8. Social contribution; and 9. Others.

- Total percentage for each item under 3 percent is not given so that the the percentage is not 100 percent.

Source : Data collected from villages survey, 2013.

\section{HOW MUCH IS THE RUPIAH EXPEN- DITURE AS THE POVERTY LINE?}

Respondents' perceptions on the rupiah expenditure in defining poverty line have almost shown no differences on the basis of social economic characteristics. In terms of educational attainment, for instance, most respondents viewed that the minimum rupiah expenditure per month for an individual was Rp 500 thousand (US\$ 40). Whilst for household with two children under elementary school age was Rp I.5 million (US\$ I20) per month. The proportion of respondents who viewed this statement was about $33.9 \%$.
Moreover, the respondents who stated the minimum rupiah expenditure per month per household with two children less than Rp 500 thousands (US $\$ 40$ ) was only $9.2 \%$. The rest of the respondents were in the group with the minimum expenditure per month of between $\mathrm{Rp} 500$ thousand and Rp I.5 million (see Table 5 for details of percentage). Note that the exchange rate of one US dollar in terms of rupiah at the time of survey was Rp I2.500. 
Table 5. Respondents' Perception on the Minimum Rupiah Expenditure by Educational Level (unit: Percent)

\begin{tabular}{|c|c|c|c|c|c|c|}
\hline \multirow[b]{2}{*}{ Educational Level } & \multicolumn{6}{|c|}{ The Minimum Rupiah Expenditure as the poverty line per month (in thousand rupiah) } \\
\hline & $<500$ & $500-750$ & $750-1000$ & $1000-1250$ & $1250-1500$ & $>1500$ \\
\hline $\begin{array}{l}\text { Not completed } \\
\text { elementary school }\end{array}$ & 4,17 & 6,11 & 4,17 & 6,94 & 6,67 & 6,67 \\
\hline $\begin{array}{l}\text { Completed El- } \\
\text { ementary School }\end{array}$ & 1,39 & 3,61 & 2,50 & 3,89 & 3,89 & 8,61 \\
\hline $\begin{array}{l}\text { Completed Junior } \\
\text { High School }\end{array}$ & 1,67 & 1,39 & 1,11 & 2,50 & 3,89 & 6,67 \\
\hline $\begin{array}{l}\text { Completed Senior } \\
\text { High School }\end{array}$ & 1,94 & 0,83 & 1,11 & 3,89 & 2,22 & 10,28 \\
\hline Diploma & 0,00 & 0,56 & 0,28 & 0,00 & 0,28 & 0,56 \\
\hline University & 0,00 & 0,00 & 0,00 & 0,28 & 0,56 & 1,11 \\
\hline Total percentage & 9,17 & 12,50 & 9,17 & 17,50 & 17,50 & 33,89 \\
\hline
\end{tabular}

Source : Data collected from villages survey, 2013.

One interesting finding was that of those respondents who viewed the minimum rupiah expenditure per month above $\mathrm{Rp} 500$ thousand (US \$40) were not only those respondents with an educational level above senior high school, but were also respondents with an elementary educational background or less. This suggests two things. First, the per capita minimum expenditure per month that was determined by the government at about Rp 250 (US\$20) or Rp 300 thousand (US\$24) as the poverty line was not realistic. The second, educational background apparently has no direct relationship with respondents' perception in judging the poverty line in terms of rupiah expenditure.

In terms of the type of employment, the finding was similar with the respondents' perception by educational level. It was stated that the poverty line that was considered by the type of employment was also Rp 500 thousands (US\$40) per capita per month or Rp I.500.000 (US\$120) per month for a household with two children. The proportion of respondents who stated this expenditure poverty line was 33.6 percent, while the proportion who stated the poverty line between Rp I.25 million and Rp I.5 million (US\$IOO-I2O) per household per month was about 17.5\%. The percentage of respondents who stated between $\mathrm{Rp}$ I million and $\mathrm{Rp}$ I.25 million (US\$ 80-IOo) per household per month was about $17.2 \%$ (Table 6).

However, it should be noted that the respondents who work as farmers tend to state the minimum expenditure of the poverty line much lower than that of the respondents who have other types of employment such as small traders and blue collar workers. This is certainly not surprising as farmers are able to consume food items from his own backyard.

In terms of the number of household members, the study found different pictures to the above findings. As can be seen in Table 7 , there was only about 9.2 percent of respondents who stated the expenditure of the poverty line of less than Rp 500 thousand (US\$40) per capita per month. The rest of the respondents tended to state the expenditure of the poverty line at the above of Rp 500 thousand per capita per month. The percentage of respondents who stated the expenditure of the poverty line above Rp I.5 million (US\$12O) per capita per month was also found to be 33.9 percent. This perception might be affected by the number of household members. 
Table 6. Respondents' Perceptions on the Expenditure Poverty Line by the Type of Employment (unit: percent)

\begin{tabular}{|c|c|c|c|c|c|c|}
\hline \multirow[b]{2}{*}{ Type of employment } & \multicolumn{6}{|c|}{ Minimum expenditure as the poverty line (in thousand rupiah) } \\
\hline & $<500$ & $500-750$ & $750-1000$ & $1000-1250$ & $1250-1500$ & $>1500$ \\
\hline $\begin{array}{l}\text { Government } \\
\text { Official }\end{array}$ & 0,00 & 0,56 & 0,00 & 0,56 & 0,83 & 0,83 \\
\hline Private workers & 0,00 & 0,28 & 0,28 & 0,28 & 0,83 & 1,11 \\
\hline Rice Farmers & 6,39 & 3,89 & 2,50 & 4,17 & 3,89 & 3,61 \\
\hline Blue collar workers & 1,11 & 2,78 & 3,06 & 5,56 & 5,56 & 12,50 \\
\hline Hawkers & 0,56 & 1,11 & 0,56 & 1,94 & 2,78 & 6,11 \\
\hline Husbandry farmers & 0,00 & 0,28 & 0,00 & 0,00 & 0,56 & 0,56 \\
\hline House wife & 0,28 & 1,67 & 0,83 & 1,11 & 0,83 & 0,83 \\
\hline Small Traders & 0,00 & 0,56 & 0,83 & 0,56 & 0,28 & 3,06 \\
\hline Unemployed & 0,56 & 1,11 & 1,11 & 1,39 & 1,39 & 0,83 \\
\hline Others & 0,28 & 0,56 & 0,00 & 1,67 & 0,56 & 4,17 \\
\hline Total percentage & 9,17 & 12,78 & 9,17 & 17,22 & 17,50 & 33,61 \\
\hline
\end{tabular}

Source : Data collected from villages survey, 2013.

Table 7. Respondents' Perceptions on the Rupiah Expenditure by the Number of Household Members (unit: Percent)

Minimum expenditure of poverty line (000)

Number of Household member $500-750 \quad 750-1.000$
$1.000-$ 1250
$1250-1500$ $>1500$

$<500$

\begin{tabular}{rrrrrrr}
\cline { 2 - 7 } & 0,83 & 0,83 & 0,56 & 0,28 & 0,83 & 0,56 \\
2 & 0,56 & 2,50 & 0,83 & 2,50 & 1,39 & 2,78 \\
3 & 1,94 & 3,06 & 1,39 & 3,33 & 3,89 & 3,89 \\
4 & 1,94 & 3,06 & 3,33 & 3,61 & 4,44 & 11,11 \\
5 & 2,22 & 1,39 & 1,11 & 3,33 & 1,94 & 6,94 \\
6 & 0,83 & 0,56 & 1,67 & 1,94 & 3,33 & 3,06 \\
7 & 0,28 & 0,56 & 0,00 & 0,83 & 1,11 & 3,06 \\
8 & 0,56 & 0,00 & 0,00 & 0,83 & 0,56 & 1,67 \\
9 & 0,00 & 0,56 & 0,28 & 0,28 & 0,00 & 0,28 \\
10 & 0,00 & 0,00 & 0,00 & 0,56 & 0,00 & 0,56 \\
& & & & & & \\
ge & 9,17 & 12,50 & 9,17 & 17,50 & 17,50 & 33,89 \\
\hline
\end{tabular}

Source: Data collected from villages survey, 2013. 
From the discussion above, it was very clear that the subjective or self-rated poverty line approach can be used to examine variables and dimensions of the poverty line. The dimensions and variables for determining the poverty line should not only be based on the adequacy of food consumption alone, but it should also take into account other non food items such as education, health, housing unit and employment.

The minimum expenditure to define the poor individual was found to be more than double the official poverty line. It was found that the minimum expenditure for an individual per month was $\mathrm{Rp} 500$ thousand or US $\$ 40$, while for a household with two children under elementary school age it was found to be about Rp I.5 million (US\$12O). These subjective poverty lines were confirmed by the respondents and based not only on educational background, but also on the type of employment. However, the respondents' perceptions of the expenditure poverty line based on the number of household members found that there was no clear answer to this question.

\section{CONCLUSION}

Criticism that claims the official poverty line has many drawbacks were confirmed from this study. The drawbacks of the official poverty line are not only in terms of variables and dimensions of the poverty line made by the government, but it was also in terms of the amount of rupiah expenditure of the poverty line. The subjective approach can be used as a method to improve the official poverty line as it accommodates more dimensions, variables and indicators of poverty.

Apart from food items, the study found that non-food items are also important and should be accommodated in defining the poor individual. These non-food items include the daily expenditures for soap, toothpaste, and the like, as well as spending for social and cultural activities, proper housing unit, and access to work. Whilst the non-food items especially education and health have been considered relatively unimportant, as these items have been given free by the government.
The amount of rupiah expenditure that should be used as the poverty line was found to be Rp 500 thousand or US $\$ 4$ o per capita per month. This subjective expenditure poverty line was almost double in comparison to the official absolute poverty line set at Rp 300 thousand (US\$24) per capita per month. While for the household with two children under elementary school age, the subjective poverty line suggested was about Rp I.5 million or US\$12O per month. Therefore, much remains to be done by the government to revise the present absolute poverty line and policies and programs to alleviate the incidence of poverty in Indonesia. If not, the incidence of poverty will always be with us.

\section{REFERENCES}

Asra, 20Io. Kemiskinan Perkotaan : Konsep, Fakta, Faktor dan Strategi, Bahan Orasi Pengukuhan Profesor Riset Bidang Ekonomi Kota dan Regional,

, 2013. Konsep dan Definisi Kemiskinan, dalam CM Firdausy (ed), Kemiskinan Alternatif di Indonesia, Laporan Penelitian, LIPI, Jakarta.

, 20II. Kemiskinan Perkotaan: Perkembangan, Determinan dan Strategi Pengentasannya. Orasi Pengukuhan Profesor Riset. BPS/LIPI. Maret 20II. Jakarta.

, 2006. Book Review on J. Weiss (editor). 2005. Poverty Targeting in Asia. Cheltenham, UK: Asian Development Bank Institute and Edward Elgar Publishing. Published in Bulletin of Indonesian Economic Studies (BIES), Vol. 42, No. 2.

, Estrada, G., Kim, Y., and Quibria, M.G. 2005. "Poverty and Foreign Aid: Evidence from Recent Cross-Country Data", ERD Working Paper Series, No. 65, Manila: ADB.

2000. "Poverty and Inequality in Indonesia: Estimates, decomposition and key issues." Journal of the Asia Pacific Economy. 5(I/2). UK: Routledge Journals, Taylor \& Francis Ltd.

1999. "Urban-Rural Differences in Costs of Living and Their Impact on Poverty Measures." Bulletin of Indonesian Economic Studies. Vol. 35. No. 3. December.

, Isidoro P. David, dan R.A. Virola. I997. "Poverty Assessment in the Philippines and Indonesia: Methodlogical Comparison." 
Journal of Philippine Development. Vol. XXIV. No. 44.

BPS, 20II. Berita Resmi Statistik. No o6 /or/th XV, 2 Januari 2012

,20I4. Berita Resmis Statistik. No. Io/02/ th $\mathrm{XX/20I4.}$

BPS, Jakarta. 20I0. Data Strategis BPS, 20Io. Berita Resmi Statistik, I July 2oro, BPS, Jakarta. ,2009. Analisa Kemiskinan, Ketenagakerjaan dan Distribusi Pendapatan, BPS, Jakarta. . 20II. Data Strategis BPS. Jakarta: BPS. 2009. Analisis dan Penghitungan Tingkat Kemiskinan 2009. Jakarta: BPS. . I984. Indikator Pemerataan Pendapatan: Jumlah dan Persentase Penduduk Miskin di Indonesia. Jakarta: BPS.

Chatterjee, S., Asra, A. and Estrada, G. 2006. "Geographical Targeting of Operations for Poverty Reduction”. Poverty and Sosial Development Papers, Technical Note No. I/July 2006, Asian Development Bank, Manila.

Clark, David., 2005. The Capability approach : Its Development, Critiques and Recent Advances, Global Poverty Research Group.

Foster, J., J. Greer, dan E. Thorbecke. I984. "A Class of Decomposable Poverty Measures." Econometrica 52(3): 76I-6.

Goedhart, T. et.al. I978. “The Poverty Line: Concept and Measurement." The Journal of Human Resources. XII.4.

Gustafsson, B. dan Ximing Yue. 2006. "Rural People’s Perception of Poverty in China." Discussion Paper No. 2486. The Institute for the Study of Labor (IZA), Bonn.

Herrera, J., M. Razaffindrakoto and F Roubaud, 2006. The determinants of subjective poverty: A Comparative analysis between Madagaskar and Peru, Document de Travail, France.

Hulme, D. et.al. 200I. "Chronic Poverty: meanings and analytical frameworks." CPRC Working Paper. No. 2. Chronic Poverty Research Centre. University of Manchester: Institute of Development Policy and Management.

Jordan, G. 2004. "The Causes of Poverty- Cultural vs. Structural: Can There Be a Synthesis?. Perspectives in Public Affairs. Spring 2004.

Kakwani, N. 2003. "Issues in Setting Absolute Poverty Lines." Poverty and Sosial Development Paper, No. 3/June. Manila: ADB.
Kingdon, G.G and John Knight, 2004. Subjective well being poverty versus income poverty and capablities poverty, Global Poverty Research Group.

Mangahas, M. 2008. "SWS Monitoring of Self-Rated Deprivation.” Makalah untuk PIDS-NEDAUNDP Project "Comprehensive Documentation and Analysis of Issues on the Official Poverty Estimation Methodology of the Philippines." 24 July.

Ravallion, M. I992. Poverty Comparisons: A Guide to Concepts and Methods. Washington, D.C.: World Bank.

Sen, A. 1999. Development as Freedom, New York.

UNDP, 2003. Promoting the Millennium Development Goals in Asia and the Pacific, New York.

Van Praag, Benard and AF Carbonnel, 2006. A Multi-dimensional Approach to Subjective Poverty. Paper presented at the conference on the measurement of Multidimensional Poverty:Theory and Evidence, UNDP, Brazilia, August 29, 2005.

Wagle, U, 2002. Rethinking Poverty: Definition and Measurement, International Sosial Science Journal, vol 54 (I7I). Hal. I55-I65.

World Bank, 2oor. World Development Report 2000/200I, Washington D.C : http:/ go.worldbank.org/7KWQQIWVTO.

2006. Making the New Indonesia Work for the Poor. Washington, D.C.: World Bank. 